\title{
Surface Analysis by Secondary lon Mass Spectrometry (SIMS): Principles and Applications from Swiss Laboratories
}

\author{
Johanna Marin Carbonne*a, Andras Kiss ${ }^{\text {bc }}$, Anne-Sophie Bouviera, Anders Meibom ${ }^{\text {ad }}$, Lukas \\ Baumgartner ${ }^{\mathrm{a}}$, Thomas Bovay ${ }^{\mathrm{a}}$, Florent Plane ${ }^{\text {ad }}$, Stephane Escrig ${ }^{\mathrm{d}}$, and Daniela Rubatto ${ }^{\mathrm{e}}$
}

\begin{abstract}
Secondary Ion Mass Spectrometry (SIMS) extracts chemical, elemental, or isotopic information about a localized area of a solid target by performing mass spectrometry on secondary ions sputtered from its surface by the impact of a beam of charged particles. This primary beam sputters ionized atoms and small molecules (as well as many neutral particles) from the upper few nanometers of the sample surface. The physical basis of SIMS has been applied to a large range of applications utilizing instruments optimized with different types of mass analyzer, either dynamic SIMS with a double focusing mass spectrometer or static SIMS with a Time of Flight (TOF) analyzer. Here, we present a short review of the principles and major applications of three different SIMS instruments located in Switzerland.
\end{abstract}

Keywords: Biology · Earth Sciences · Mass Spectrometry · NanoSIMS · SIMS · Surface analyses · TOF-SIMS

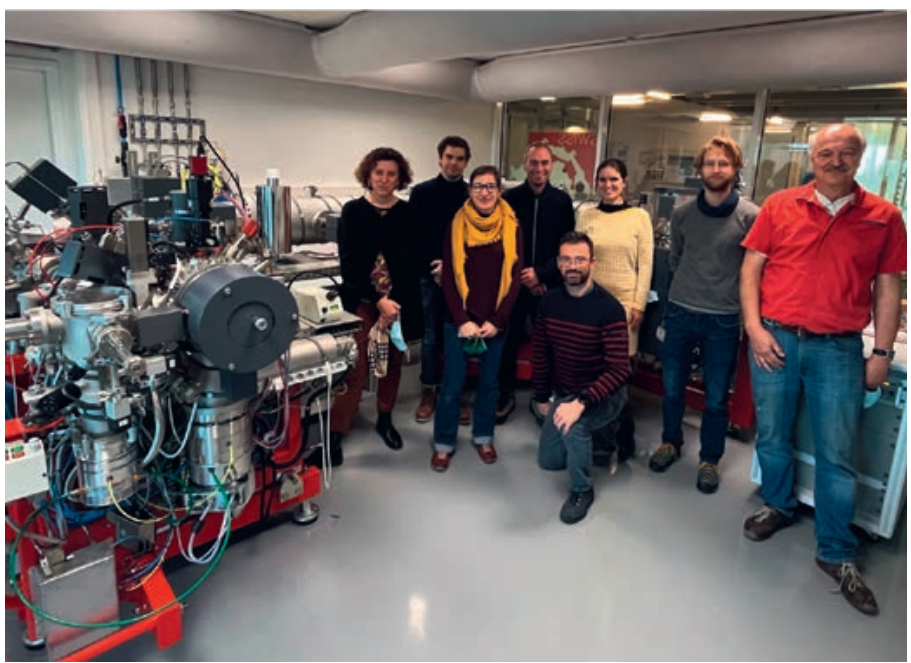

From left to right, Prof Rubatto, Mr Plan, Dr Bouvier, Prof Meibom, Dr Escrig, Prof Marin Carbonne, Dr Bovay and Prof Baumgartner in front of the SwissSIMS 1280 instrument in the Center of Advanced Surface Analyses, a joint facility between UNIL and EPFL

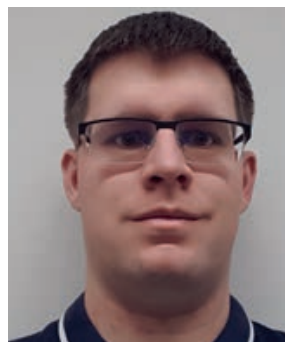

Dr. Kiss is responsible for the TOF-SIMS instrument of the Laboratory of Advanced Technology at University of Geneva.

\section{Principles of Secondary Ion Mass Spectrometry}

The basic principle of Secondary Ion Mass Spectrometry, hereafter called SIMS, is that a finely focused primary ion beam sputters a solid sample surface. ${ }^{[1]}$ A mass spectrum of ionized particles ejected from the pit due to collision cascade reactions is measured to determine either molecular, elemental, or isotopic properties of the sample. SIMS instruments can be operated in either 'static' or 'dynamic' modes which are optimized in different instruments equipped with different types of mass analyzer. In the so-called static SIMS regime, the primary ion dose is kept below $\sim 1 \times 10^{13}$ ions $/ \mathrm{cm}^{2}$. In this regime, less than $1 \%$ of the measured sample surface area is sputtered, resulting in minimal mixing and fragmentation of molecules on the sample surface. In contrast, dynamic SIMS uses high primary ion beam doses to continually erode a sputter pit. Such analyses are optimized for high precision and high sensitivity isotopic and trace element information as almost all molecular information is destroyed by ion beam mixing during the sputtering process.

The mass analyzer used in static SIMS measures the Time-ofFlight (TOF) of secondary ions as heavier ions lag behind lighter ions. A TOF-SIMS can detect all the generated secondary ions regardless of mass in a single measurement allowing the analysis of both intact small organic compounds and elements at the same time. TOF-SIMS instruments generally have to use pulsed primary ion sources for sample analysis, as the TOF-SIMS analyzer requires a well-defined starting point for the flight time measurement. Nowadays the most common ion sources for TOF-SIMS are the liquid metal ion guns (LMIG), operating with $\mathrm{Ga}, \mathrm{Au}$ or Bi. Additionally, the use of the $\mathrm{Au}$ and $\mathrm{Bi}$ cluster sources result in a 100-1000-fold increase in ion yield compared to the Ga source. ${ }^{[2,3]}$ A recent addition is the ion source using $\mathrm{C}_{60}{ }^{[4,5]}$ and with the introduction of the $\mathrm{J} 105$ mass spectrometer, ${ }^{[6]}$ where the primary ion source is operated in continuous mode and the secondary ions are pulsed, the use of large cluster ion beams (with $\mathrm{Ar}_{,}{ }^{[7]} \mathrm{CO}_{2}{ }^{[8]}$ or

${ }^{*}$ Correspondence: Prof. J Marin-Carbonne ${ }^{a}$, E-mail: johanna.marincarbonne@unil.ch aEarth Sciences Institute, University of Lausanne, Geopolis Mouline, CH 1015 Lausanne; 'Laboratory of Advanced Technology (LTA), Quai E. Ansermet 24, CH 1211 Geneva; 'Department of Quantum Matter Physics (DQMP), University of Geneva, Quai E. Ansermet 24, CH 1211 Geneva; 'Laboratory for biological geochemistry, Ecole Polytechnique Fédérale de Lausanne (EPFL), CH-1015 Lausanne, Switzerland; eInstitute of Geological Sciences, University of Bern, Balzerstrasse 1+3, CH 3012 Bern 
$\mathrm{H}_{2} \mathrm{O}^{[9]}$ ) also became possible. These last two ion sources sacrifice some of the spatial resolution of the LMIGs for a further increase in the molecular ion yield, thus also increasing the accessible mass range of the technique. TOF-SIMS instruments are also capable of performing depth-profiling experiments, but since most of the surface is not sputtered in static SIMS mode, it is necessary to alternate separate analysis and sputtering cycles to remove the already analyzed surface layer. The separate measurement and sputtering cycles mean that the analytical beam and the sputter beam do not have to be the same and can be optimized separately. This results in different optimal sputter ion sources for the depth profiling of inorganic material and elemental studies such as monoatomic $\mathrm{Ar}^{+}$, $\mathrm{O}_{2}^{+}$and $\mathrm{Cs}^{+}$ion sources or $\mathrm{C}_{60}{ }^{+}$and large gas cluster ion sources for the depth profiling of organic samples. Compared to other surface analytical methods, TOF-SIMS is extremely surface sensitive, with a lateral resolution that can go below $100 \mathrm{~nm}$. According to some publications even reaching sub-20 nm spatial resolution ${ }^{[10]}$ is possible. The fact that it only samples the top few $\mathrm{nm}$ of the sample and its high sensitivity makes it an ideal method to study surface contaminations and material defects while the high spatial resolution and the capability to generate intact molecular ions can provide chemical imaging on the single cell level.

In dynamic SIMS, the charged particles called secondary ions are accelerated by an electrostatic field and injected into a double focusing mass spectrometer where the ions are separated according to their energy and mass/charge ratio and finally counted by either faraday cups or electron multipliers. ${ }^{[11,12]}$ The primary ion beam either uses positive ions or negative ions according to the polarity of the measured secondary ions. The two sources classically used are a Cs source producing $\mathrm{Cs}^{+}$, which enhances the yield of negatively charged secondary ions, or a plasma source producing an $\mathrm{O}^{-}$beam, for analysis of positive secondary ions, especially from electrically insulating samples. Two state-of-theart dynamic SIMS instruments are the large radius SIMS and the NanoSIMS. All elements from the periodic table from $\mathrm{H}$ to $\mathrm{U}$ (except noble gases) can be quantitatively analyzed (not simultaneously) under different modes: single spot analysis, depth profiling and secondary ion imaging, surface sputtering. In single spot analysis, the primary ion beam is finely focused on a static spot with size ranging from less than $100 \mathrm{~nm}$ up to $40-50 \mu \mathrm{m}$. This mode allows the measurement of elemental concentrations and/or isotope compositions of single mineral grains. ${ }^{[13-17]}$ In secondary ion imaging mode, the SIMS produces the distribution of elements and/or isotopes on a spatially resolved image ${ }^{[18-20]}$ of an area up to $500 \mu \mathrm{m}^{2}$. The NanoSIMS has been designed to achieve a high lateral resolution (less than $100 \mathrm{~nm}$ ) with the drawback of extracting lower intensity secondary ion beams than the other SIMS using a bigger beam size, and thus having a lower precision on isotope ratios in the imaging mode. The high energy of the NanoSIMS primary beam (typically several kilo-electron volts) yields to the extraction of atoms and small molecules from the first 10-20 nnm of the sample, preventing the NanoSIMS from having as high a depth-resolution as some other SIMS instruments.

Depth profiling can however be performed on the other dynamic SIMS instruments by allowing the collection of secondary ions as the primary ion beam continuously erodes the surface of a slowly sputtered pit, 'peeling' off layer by layer of atoms. It is used to determine concentration and isotope composition variations with depth. ${ }^{[18,21-23]}$ For more details, the reader can refer to the existing reviews and books on dynamic SIMS principles and applications. ${ }^{[24,25]}$

The SIMS technique is considered quasi non-destructive as only a small volume of the sample is consumed during analysis, between 10 to $1000 \mu \mathrm{m}^{3}$ depending on the intensity and the focus of the primary ion beam and the specific applications (Fig. 1). As a surface analysis technique, SIMS requires careful sample preparation including several steps of polishing down to a surface roughness less than $0.5 \mu \mathrm{m}$. Surface topography $>5 \mu \mathrm{m}$ can create differential sputtering and analytical bias in the measurements. ${ }^{[26]}$ Several factors need to be properly corrected for quantitative analysis by SIMS, as ion yields and instrumental mass fractionation must be calibrated by use of standard materials. Matrix effects, crystal orientation, drift in backgrounds and yields of the detectors and Quasi Simultaneous Arrival (QSA) can affect the results when analyzing ions with high ionization yields ${ }^{[27-30]}$ and needs to be corrected for accuracy and high precision of the measurements. Sputtering generally produces large isotope mass dependent fractionation of secondary ions, up to several permille, the magnitude of which can also depend on the chemical and structural environment of the analyzed area of the sample. ${ }^{[31-36]}$ An example of such a 'matrix effect' is how the oxygen isotope instrumental mass fractionation in carbonate is different between aragonite and calcite due to the different crystallographic structure ${ }^{[37]}$ but also in calcite with various $\mathrm{Mg}, \mathrm{Fe}$ and $\mathrm{Mn}$ content. ${ }^{[35,38]}$ As theoretical models of ion sputtering cannot predict quantitatively the matrix effect, ${ }^{[29]}$ corrections of isotope measurements are empirical, using matrix matching reference materials ('standards'). The matrix effects have been extensively studied for glass, silicates and carbonates but also for sulfides and oxides. ${ }^{[29]}$

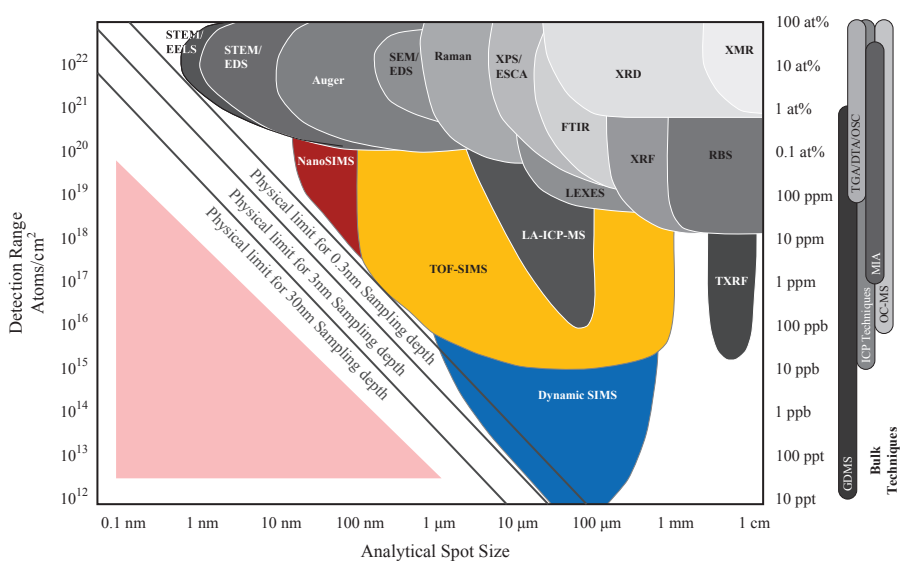

Fig. 1. Sensitivity and spatial resolution of the SIMS techniques compared to other analytical methods (adapted from Evans Analytical Group $\left.{ }^{[43]}\right)$.

Below we present the basic principles and main applications of TOF-SIMS, dynamic SIMS, and NanoSIMS from three different laboratories in Switzerland. It is worth noting that there are two other TOF-SIMS instruments in the academic landscape of Switzerland; a TOF.SIMS 5 (ION-TOF GmbH) and a TOF-SIMS instrument integrated in a FIB-SEM system (both at EMPA, in Dübendorf and Thun, respectively) but are not described in detail here.

\section{TOF-SIMS \\ 2.1 Presentation}

In 2019, the Laboratory of Advanced Technology (LTA) obtained a Physical Electronics nanoTOF II TOF-SIMS instrument (Fig. 2) as part of its high-performance chemical analysis and imaging platform located at the University of Geneva. The platform is open to researchers at universities and research institutes in- and outside of Switzerland and to companies in need of high-performance chemical analysis services.

The mass spectrometer is equipped with a Bi LMIG as the primary ion beam, capable of generating a beam of different $\mathrm{Bi}$ ions $\left(\mathrm{Bi}^{+}, \mathrm{Bi}_{3}^{+}, \mathrm{Bi}_{3}{ }^{2+}\right)$. The minimum spot size of the analytical beam is around $70 \mathrm{~nm}$. The instrument has a wide selection of sputter 

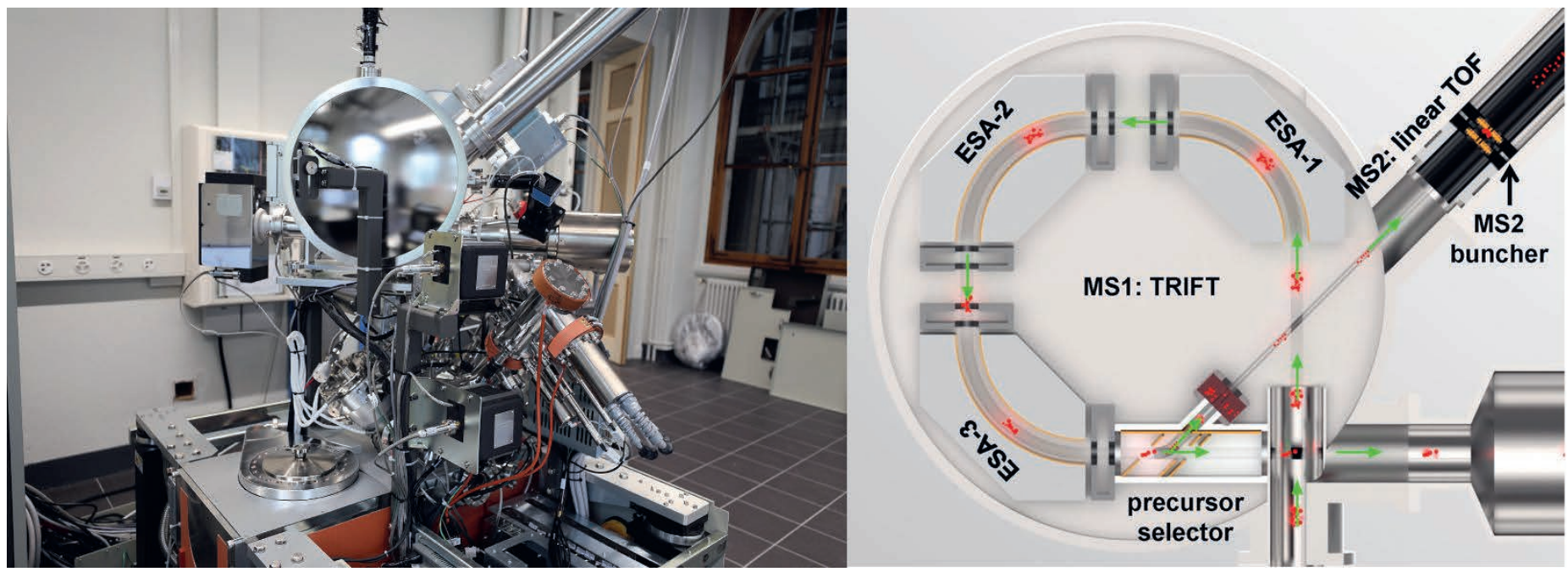

Fig. 2. The TOF-SIMS laboratory of LTA showing the TRIFT mass analyzer of the MSMS capable nanoTOF II mass spectrometer. Adapted with permission from Fisher et al. 2016 ${ }^{[39]}$ )

beams for depth profiling. Besides the Bi LMIG, it has a dual gas beam that can either operate with $\mathrm{Ar}$ or $\mathrm{O}_{2}$ and is mainly useful for the depth profiling of inorganic materials, and a gas cluster beam that can generate large Ar cluster ions and is suitable for the depth profiling of organic compounds. Finally, it has tandem MS capabilities to enable the identification of larger organic and inorganic secondary ions. ${ }^{[39]}$

\subsection{Applications}

TOF-SIMS has a wide range of applications ranging from materials science, ${ }^{[40-45]}$ art restoration and research, ${ }^{[46,47]}$ foren$\operatorname{sics}^{[48-50]}$ or earth sciences and cosmochemistry. ${ }^{[51-56]}$ TOF-SIMS was originally primarily applied in the field of materials science because the first primary ion sources were only capable of generating elemental ions and very small organic fragments. This remains one of the main fields where TOF-SIMS is extensively used. The possible application areas include the determination of the composition of glasses, ${ }^{[42]}$ semiconductor samples, ${ }^{[43]}$ photovoltaic systems ${ }^{[40,44]}$ or the study of paints and other surface coatings. ${ }^{[41]}$ The capability of TOF-SIMS to analyze mixed organic-inorganic materials makes it a suitable tool for the study of photovoltaic materials and especially perovskite solar cells. ${ }^{[44]}$

Depth profiling and 2D and 3D high spatial resolution imaging highlighted the chemical changes during manufacture and operation in perovskite. Inhomogeneities detected in the distribution of a passivating agent on grain boundaries was linked to the performance of the solar cells. TOF-SIMS is one of the standard chemical analysis techniques used in battery research ${ }^{[45]}$ mainly because of its high sensitivity to elements, especially to light elements such as lithium. It is mostly used for depth profiling to study the diffusion of compounds between the different components of the battery. A depth profile of a solid state battery revealed a distinct interlayer in the cathode material on the electrolyte/cathode interface. ${ }^{[45]}$ This interlayer was completely gone when the thickness of the electrolyte layer was decreased.

TOF-SIMS is proving to be increasingly useful in the field of biomedical research. The instrument at the LTA has been used, for example, for investigating chemical changes in the dentin after different treatments of tooth samples (Fig. 3). ${ }^{[57]}$ In this example, the capability of TOF-SIMS to detect inorganic and organic ions simultaneously proved to be advantageous as it allowed the high spatial resolution imaging of apatite, collagen and riboflavin at the same time. The results showed an almost complete lack of apatite-related ions due to the complete demineralization of the dentin after phos- phoric acid treatment and the remineralization of the samples after calcium-phosphate and riboflavin treatment. The TOF-SIMS results were linked with how carious dentin behaves during restoration after these different treatments. Probably the most successful applications of TOF-SIMS in the field of biomedical studies involve the imaging of lipid distributions in tissue sections. TOF-SIMS measurements were applied among others for the study of various diseases including several different tumor types, ${ }^{[58-62]}$ osteoarthritis, ${ }^{[63]}$ Alzheimer's disease, ${ }^{[64]}$ and Duchen's muscular dystrophy. ${ }^{[65]}$ A study of osteoarthritic cartilage samples showed the formation of lipid droplets in the superficial layer of osteoarthritic cartilages whereas such droplets were absent in healthy samples.[63]
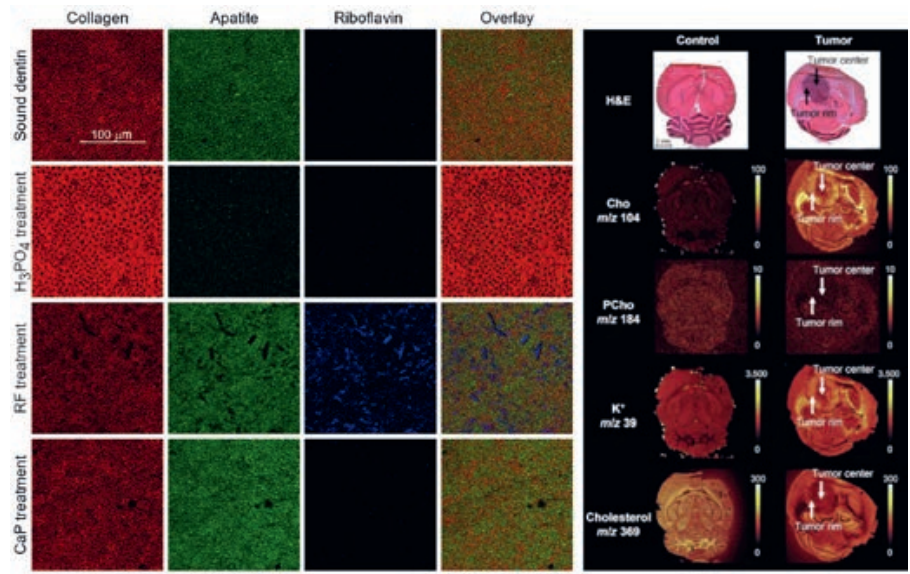

Fig. 3. Examples for the application of TOF-SIMS. Imaging organic and inorganic constituents of dentin samples after various treatments (Reproduced from Betancourt et al. 2021 ${ }^{[57]}$ ) and imaging of the distribution of low molecular weight metabolites in a glioma sample (Reproduced with permission from Wehrl et al. 2013 ${ }^{[62]}$ ).

The applicability of TOF-SIMS for the measurement of proteins is limited because most of the species detected are small amino acid fragments. However, it is possible to use TOF-SIMS in simple systems where only a single protein is present, such as the study of protein adsorption on surfaces or where a single protein species constitutes the bulk of the protein content of the samples. ${ }^{[66]}$ For the latter, the study of teeth samples described 
above is a good example as collagen is the most abundant protein present in these samples. ${ }^{[57]}$

In recent years, there have been a few examples where a technique called matrix enhanced SIMS (ME-SIMS) was able to detect neuropeptides directly from tissue sections ${ }^{[67]}$ or in combination with liquid chromatography was capable of identifying proteins in a conventional top-down proteomics workflow. ${ }^{[68]}$ However, due to the difficulties with getting a suitably homogeneous matrix layer and the loss of spatial resolution due to the matrix crystal size this technique has not seen widespread application.

Finally, a method called Multiplexed Ion Beam Imaging was developed by Angelo et al. for the TOF-SIMS analysis of proteins. ${ }^{[58]}$ In this method, selected proteins of interests are labelled with lanthanide isotope tagged antibodies. TOF-SIMS is capable of imaging the different metal isotope tags with high sensitivity and spatial resolution, thus enabling the parallel imaging of more than 40 proteins. These capabilities were demonstrated in the study of immune response in breast cancer samples. ${ }^{[59]}$

TOF-SIMS is not as frequently used in the field of earth sciences as the other SIMS methods. However, several examples can be found in the literature where it was used for the high spatial resolution imaging of light elements such as $\mathrm{Li}$ and $\mathrm{B}$ in different minerals ${ }^{[51,54,55]}$ or for the imaging of a wide range of trace elements in melt inclusions. ${ }^{[52]}$ Another example is the measurement of volatiles in apatite, ${ }^{[53]}$ which detected the presence of $\mathrm{OH}^{-}$in fluoroapatite from a lunar basalt sample. An interesting example of the use of TOF-SIMS in earth sciences is the work by Rinnen et al. ${ }^{[56]}$ They measured the composition of a series of different minerals by TOF-SIMS and used principal component analysis to build a model that can be used to differentiate and identify different minerals in rock samples based on their TOF-SIMS signal.

\section{Dynamic SIMS \\ 3.1 Presentation}

The SwissSIMS laboratory is equipped with a CAMECA IMS $1280 \mathrm{HR}$ ion microprobe (Fig. 4) that was installed at the University of Lausanne in August 2012. The SwissSIMS instrument has been acquired by a consortium of different Swiss universities (University of Geneva, Bern and Lausanne) and ETHZ, associated with the Swiss National Science Foundation. This laboratory is a national facility used for high spatial resolution in situ elemental and isotopic analysis, open to all researchers based in or outside Switzerland, after reviews of their analytic proposal. A large diversity of projects has been done, mostly in earth sciences.

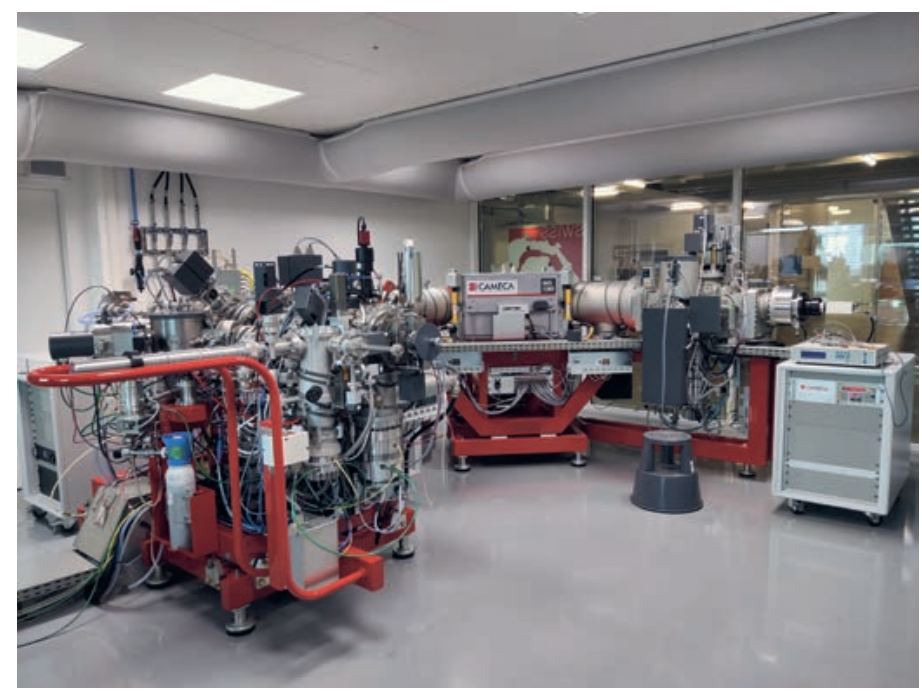

Fig. 4. The CAMECA IMS $1280 \mathrm{HR}$ in the SwissSIMS laboratory.
The 1280HR ion microprobe has two primary ion sources: a $\mathrm{Cs}^{+}$source and a high density, newly developed, Hyperion RF plasma source $\left(\mathrm{O}^{-} / \mathrm{O}^{-}\right)$. The Hyperion RF Plasma source was installed in 2019 and allows to reduce the size of the focused spot compared to an equivalent intensity beam from the Duoplasmatron $\left(\mathrm{O}^{-} / \mathrm{O}_{2}^{-}\right)$source originally installed. ${ }^{69,70]}$ The primary ions are accelerated with a 10 or $13 \mathrm{kV}$ voltage through a primary column equipped with lenses and apertures used to focus and shape the beam. For many analyses, the beam size is typically 10-15 microns diameter, but down to 3 microns spots are also possible in some cases, especially using the Hyperion source. The SwissSIMS is equipped with a multicollection system, allowing the simultaneous detection of 2 to 5 elements with mass ratio up to 1.17. The mass spectrometer can be operated in monocollection mode by peak jumping over a wide range of masses. A new Faraday cup with a $10^{12}$ feedback resistor has been recently acquired, ${ }^{[71]}$ allowing more precise measurements of some minor isotopes, such as ${ }^{17} \mathrm{O}$ and ${ }^{36} \mathrm{~S} .{ }^{[15]}$

\subsection{Applications}

Since its installation, the SwissSIMS ion microprobe has been used primarily to determine stable isotope compositions in a wide range of silicates, carbonates, phosphates, sulfides or metals. ${ }^{[31,32,34,69,72-79]}$ Beside the measurement of stable isotopes, the SwissSIMS instrument has been used for $\mathrm{U}-\mathrm{Pb}$ dating and trace element determination in zircons and monazite. ${ }^{[80-82]}$ The SwissSIMS has also proven to be a powerful tool for the determination of diffusion coefficients of trace elements thanks to its capacity to perform analysis in depth profiling mode. ${ }^{[21,83,84]}$ Finally, due to the ultra-high vacuum in the SIMS $\left(10^{-10} \mathrm{~Pa}\right)$, the instrument is particularly useful for the determination of low concentration volatile elements. ${ }^{[34,85,86]}$

In order to allow a large variety of projects to be done, the SwissSIMS has developed new reference materials and new analytical protocols appropriate for applications such as $\mathrm{Cl}$ isotopes in glasses, ${ }^{[73]} \mathrm{S}$ in apatite, ${ }^{[87]} \mathrm{Li}$ and $\mathrm{O}$ isotopes in garnet, ${ }^{[32,88]} \mathrm{O}$ and $\mathrm{B}$ isotopes in tourmaline, ${ }^{[78]} \delta^{18} \mathrm{O}$ and volatiles in micas and biotite. ${ }^{[34,85]}$ The development of these methods has a large impact on different fields of earth sciences. For example, the development of $\mathrm{B}$ and $\mathrm{O}$ isotope reference materials in tourmalines, or $\mathrm{O}$ in monazite and garnet, or $\mathrm{S}$ in apatite allows the SwissSIMS to be applied to the field of ore deposit studies and metamorphic petrology. For example, Harlaux et al. reported $\delta^{18} \mathrm{O}$ and $\delta^{11} \mathrm{~B}$ in different tourmalines from a San Rafael (Peru) tin(-copper) ore deposit. ${ }^{[89]}$ Their results show that syn-ore hydrothermal tourmaline has distinct $\delta^{18} \mathrm{O}$ and $\delta^{11} \mathrm{~B}$ compared to late-magmatic and pre-ore hydrothermal tourmaline. The modelling of $\delta^{18} \mathrm{O}$ and $\delta^{11} \mathrm{~B}$ compositions suggests that tourmaline crystallized in a continuously evolving magmatic-hydrothermal system. The isotopic composition of the syn-ore hydrothermal tourmaline instead suggests variable degrees of mixing of hot, Sn-rich magmatic brine with meteoric groundwater, revealing the importance of fluid mixing to trigger cassiterite deposition. Another example of the application of the developed tourmaline reference material is from Marger et al., who combined measurements of $\delta^{18} \mathrm{O}$ in tourmaline and $\delta^{18} \mathrm{O}$ in quartz from the same samples in order to investigate the origin of the Monte Rosa whiteschists (Western Alps). ${ }^{[90]}$ Associated with a careful petrological study, the results enabled the conclusion that the tourmaline-bearing white-schist of Monte Rosa Nappe originated from the related meta-leucogranites. Furthermore, late magmatic hydrothermal fluids altered the meta-leucogranite prior to Alpine high-pressure metamorphism.

While a single set of standards developed by the SwissSIMS laboratory can be used for different purposes, several different reference materials and analytical techniques have also been developed for a single purpose, such as for the determination of 
the origin of fluids in subduction zones. For example, Manzini et al. developed $\mathrm{Cl}$ isotopes measurements in glasses, which could be used to track the deep $\mathrm{Cl}$ cycle. ${ }^{[91]}$ Also, protocols and standards for the analysis of oxygen isotopes in garnet have been optimized for the SwissSIMS. This included defining a matrix correction curve for the grossular, spessartine and andradite components based on sixteen reference garnet samples. Additionally, in order to improve the precision of the matrix correction, three new garnets with grossular content between 32 and $88 \%$ were characterized. ${ }^{[32]}$ In a first application, oxygen isotope data from garnet combined with isotopic modelling resolved multistage fluid percolation in continental crust during oceanic alteration and subsequent subduction (Sesia Zone, Western Alps). ${ }^{[92]}$ A study of garnet in subducted oceanic crust revealed that pervasive fluid flow occurred at high pressure and that the integrated fluid flux was comparable to the high values documented in metasomatic rocks and veins. [93]

The recent acquisition of the Hyperion RF Plasma source has enabled the development of $\mathrm{Fe}$ isotope composition analyses in micrometric sulfides (Fig 5). This new protocol has allowed to target submicrometric sulfides associated with organic matter in ancient fossil rocks, stromatolites from the Precambrian. ${ }^{[69,94]}$ The $\mathrm{Fe}$ isotope composition of these sulfides have revealed a complex cycle of oxidation and reduction processes mostly driven by microbial activities and thus highlights the presence of a microbial ecosystem at 2.7 $\mathrm{Ga}^{\left[{ }^{[94]}\right.}$

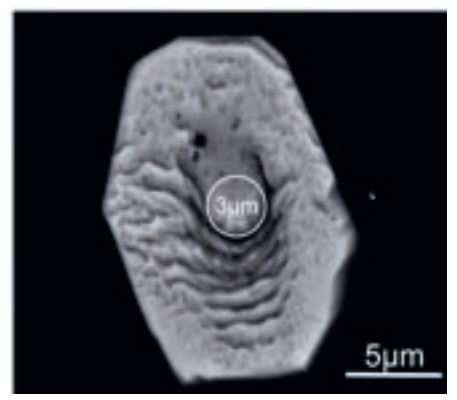

Fig. 5. Example of dynamic SIMS applications, development of analysis of Fe isotope with a $3 \mu \mathrm{m}$ spot size showing the microphotograph of pyrite with the SIMS crater, (Adapted from Decraene et al. 2021 $1^{[94)}$ ). Note that the reproducibility obtained on standards is comparable to the reproducibility obtained by bulk measurements by MC-ICPMS.

\section{NanoSIMS}

\subsection{Presentation}

The laboratory for Biological Geochemistry at EPFL hosts a NanoSIMS 50L instrument, which is a dynamic, double-focusing, magnetic-sector, multi-collecting ion probe (Fig. 6). The distinguishing feature of the NanoSIMS ion microprobe is its ability to focus the primary beam (either $\mathrm{Cs}^{+}$or $\mathrm{O}^{-}$) onto an extremely small spot on the sample surface, smaller than $100 \mathrm{~nm}$ in linear dimension. A controlled raster of this highly focused primary beam across the sample surface therefore allows secondary ion images to be produced with a spatial resolution that can resolve structures larger than a few hundred nanometers in linear dimension. In recent studies it has been possible to resolve substructures of the cell nucleus, such as nucleolus (polymerase RNA), chromatin (DNA) packages, along with individual clusters of glycogen in both liver and brain cells from mice. ${ }^{95,96]}$ Mass-resolving power sufficient to unambiguously distinguish the isotope of interest from nearby interferences is achieved even at very high transmission for most isotopic systems of relevance to biological samples. This allows relatively precise isotopic and elemental ratios to be quantitatively mapped in a wide range of solids, including biological materials, on length scales much smaller than one micrometer.

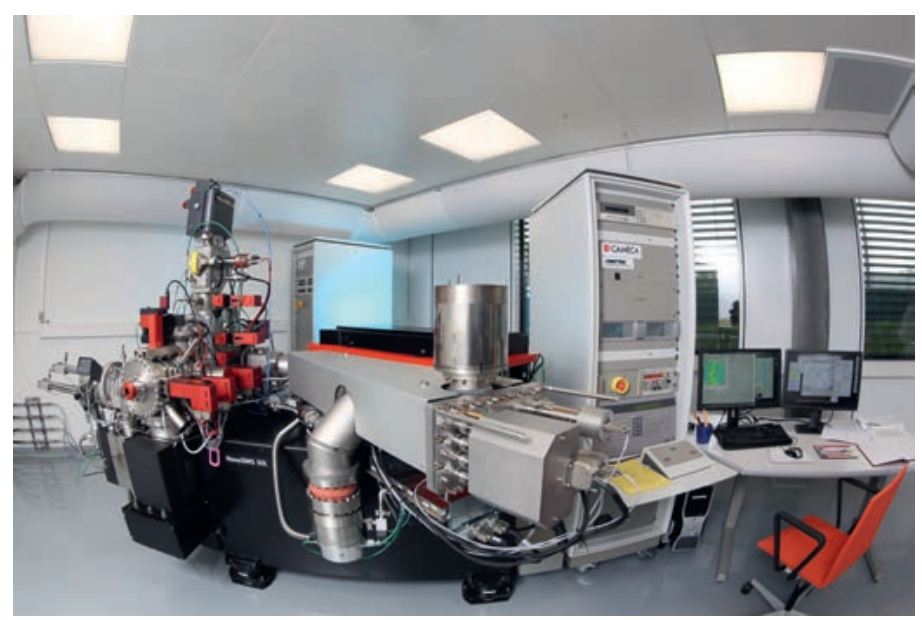

Fig. 6. The NanoSIMS 50L instrument in the Laboratory for Biological Geochemistry (LGB) at the EPFL, Switzerland, which is part of the Center for Advanced Surface Analysis established between EPFL and University of Lausanne.

Technical notes of importance are that for insulating materials, sample surface charging due to $\mathrm{Cs}^{+}$bombardment can be compensated with an electron gun, and the NanoSIMS 50L instrument is equipped with a multi-collector system permitting collection of up to seven different ions simultaneously, i.e. seven different isotopic images can be recorded at the same time from the same area on the sample surface. This capability is used to create images or maps of elemental and isotopic variation within a sample from the lightest elements, such as $\mathrm{H}\left(\right.$ e.g. D/H ratios), $\mathrm{C}\left({ }^{13} \mathrm{C} /{ }^{12} \mathrm{C}\right.$ ratios), $\mathrm{N}\left({ }^{15} \mathrm{~N} /{ }^{14} \mathrm{~N}\right.$ ratios), $\mathrm{O}\left({ }^{17} \mathrm{O} /{ }^{16} \mathrm{O}\right.$ and ${ }^{18} \mathrm{O} /{ }^{16} \mathrm{O}$ ratios) and $\mathrm{S}$ (e.g. ${ }^{34} \mathrm{~S} /{ }^{32} \mathrm{~S}$ ratios), to the heaviest elements in the periodic table, including uranium.

\subsection{Applications}

The NanoSIMS was primarily developed to produce images of large chemical or isotopic variations in solid samples, when high spatial resolution is needed to resolve sub-micrometer structures with relatively modest analytical precision. It is therefore the perfect analytical instrument in conjunction with biological labelling experiments, where high spatial resolution is required and extremely high analytical precision is not a strict requirement.

The NanoSIMS has been used for cosmochemical applications for a decade and has revolutionized studies of sub-micrometer, pre-solar grains in meteorites, and boosted many other aspects of in situ isotopic studies of extraterrestrial matter; reviewed in ref. [12]. Over the last decade, a number of equally remarkable scientific publications using NanoSIMS to study geological and geo-biological materials have appeared, e.g. pertaining to the emergence of life and trophic interactions in ancient microbial ecosystems. ${ }^{[97-100]}$ In addition, NanoSIMS studies using ${ }^{13} \mathrm{C}$ and ${ }^{15} \mathrm{~N}$-labeled micronutrients, combined with e.g. fluorescence in situ hybridization (FISH) and related techniques have yielded unique insights into the eco-physiology of modern bacteria and archaea within complex microbial communities. ${ }^{[101-108]}$ The NanoSIMS technology is still not widely used in the Life Sciences or among biologists in general, in part because of the relatively few instruments available. Despite this, the NanoSIMS is now 
increasingly playing a pivotal role in a number of fundamental and applied biological studies on tissues as diverse as brain, heart, and liver, over plants, to stem cells. ${ }^{[103,109-117]}$

\section{Conclusions and Perspectives}

Few studies have demonstrated the complementary nature of these three different SIMS instruments. For example, a recent study has shown that Ti diffusion in zircon is highly anistropic by performing depth profiles using SIMS and NanoSIMS.[118] The combination of NanoSIMS and TOF-SIMS was used by Leitner et al. to study the composition of a presolar stardust grain. ${ }^{[119]}$

Analytical developments in the field of SIMS are currently focused on the performance of ion sources that can lead to an increased spatial resolution and/or ionization efficiency. This will in turn lead to improved limits of detection of secondary ions and, in the case of TOF-SIMS, the identification of unknown ions. As already discussed, for dynamic SIMS and NanoSIMS, new plasma sources have been recently developed that can increase both the sensitivity and the spatial resolution. ${ }^{[69,70]}$

One of the most important innovations in the field of TOFSIMS instrumentation was the introduction of commercial instruments with improved identification capabilities. The improvements in detecting intact organic molecules in TOF-SIMS instruments necessitated the inclusion of tandem mass spectrometer capabilities to help with the identification of intact organic ions. One of the main goals of the development of new TOF-SIMS instruments is to decrease the fragmentation of organic molecules and to improve the ionization efficiency thereby extending the applicability of the technique for imaging intact organic molecules. The decrease in fragmentation can be achieved by developing new ion sources, such as the recent introduction of ion sources utilizing large water cluster ions as primary ions. ${ }^{[8,9]}$ Increasing the ionization efficiency of SIMS ion sources would increase the sensitivity of the technique considerably, especially close to the spatial resolution limit, where the sampled volume becomes very small and generally only the most abundant species can be detected. For example, the water cluster ion source has the advantage over the argon cluster ion sources that the primary ions can participate in proton transfer reactions, increasing the ion yield of the technique. ${ }^{[9]}$ Increasing the ionized fraction can also be achieved by introducing laser post ionization ${ }^{[120-122]}$ in the mass spectrometer to ionize the additional neutral species ejected from the sample. Indeed, most of the sputtered species are neutral and only a very small percentage of the ejected species are actually ionized in SIMS. Besides the increased sensitivity, an additional advantage of using laser post-ionization is that the signal becomes independent of the quality of the surface. In other words, the postionization can decrease the matrix effects and as a result, it could aid the quantitation of compounds present on the surface. ${ }^{[120]}$ For example, new resonance ionization mass spectrometers can achieve high spatial resolution and high sensitivity by combining a TOF-SIMS with laser ionization instruments. ${ }^{[123]}$

Future developments are also focusing on increasing the spatial resolution of the SIMS. Scanning mode imaging allows to image an area pixel by pixel with a tightly focused beam. The ions generated from the imaged area are sent through a TOF analyzer with stigmatic imaging capabilities. This means that the ions retain their spatial position while flying through the mass analyzer and they are detected on a position sensitive detector that records both their position and their flight time. The main advantage of the method is that the spatial resolution is determined by the pixel size of the detector or by aberration in the ion image (i.e. ion optics) instead of the focusing of the primary ion beam. However, the method has been limited by the lack of suitable position sensitive detectors. There have been proof-of-concept experiments with the combination of phosphor screens and CCD cameras, ${ }^{[124]}$ delay line detectors ${ }^{[125]}$ and active pixel detectors. ${ }^{[126]}$ With im- provements in the field of position sensitive detectors, microscope mode imaging can become a viable option in the future. A solid state imaging detector called SCAPS has been installed on some dynamic SIMS instruments that allow direct ion imaging of small mineral samples and allow the detection of isotope or chemical anomalies at a high spatial resolution, generally a few tenths of a micron. ${ }^{[127-130]}$

Future improvements of the detection capabilities of SIMS will consist of the introduction of new faraday cups with higher sensitivity amplifiers or the development of new ion detectors that will allow measurement of low intensity signals (i.e. minor isotopes) with a better precision and accuracy. ${ }^{[71]}$

New sample preparation methods in the future can also increase SIMS applications in biomedical studies. In the recent years, measuring frozen tissue sections under cryo-conditions has started to see a more widespread use and it is expected that this trend will continue as it prevents the diffusion of mobile compounds in tissue sections and arrests enzymatic processes to preserve the chemical composition of biological samples. As a result, it can enable the imaging of high turnover metabolites and mobile lipid species. ${ }^{[131-133]}$

In conclusion, SIMS is a versatile technique that analyses secondary ions sputtered from the sample surface. Depending on the instrument, the spatial resolution and the detection will be very different, enabling a large diversity of scientific applications from material and earth sciences to biological and biomedical studies.

\section{Acknowledgements}

The SwissSIMS facility is funded by UNIL, UNIBE, UNIGE and ETHZ, a starting grant by SEFRI (KIP6) and by the FNS. We thank all the CASA members and the various users and collaborators of the SwissSIMS. We thank K. McKeegan and one anonymous reviewer for their constructive reviews of the manuscript.

Received: November 29, 2021

[1] A. Benninghoven, Surf. Sci. 1994, 299, 246, https://doi.org/10.1016/0039-6028(94)90658-0.

[2] N. Davies, D. E. Weibel, P. Blenkinsopp, N. Lockyer, R. Hill, J. C. Vickerman, Appl. Surf. Sci. 2003, 203, 223 https://doi.org/10.1016/S0169-4332(02)00631-1.

[3] D. Touboul, F. Kollmer, E. Niehuis, A. Brunelle, O Laprévote, J. Am. Soc. Mass Spectrom. 2005, 16, 1608 , https://doi.org/10.1016/j.jasms.2005.06.005.

[4] D. Weibel, S. Wong, N. Lockyer, P. Blenkinsopp, R. Hill, J. C. Vickerman, Anal. Chem. 2003, 75, 1754, https://doi.org/10.1021/ac026338o.

[5] S. C. C. Wong, R. Hill, P. Blenkinsopp, N. P. Lockyer, D. E. Weibel, J. C. Vickerman, Appl. Surf. Sci. 2003, 203, 219, https://doi.org/10.1016/S0169-4332(02)00629-3.

[6] J. S. Fletcher, S. Rabbani, A. Henderson, P. Blenkinsopp, S. P. Thompson, N. P. Lockyer, J. C. Vickerman, Anal. Chem. 2008, 80, 9058, https://doi.org/10.1021/ac8015278.

[7] S. Rabbani, A. M. Barber, J. S. Fletcher, N. P. Lockyer, J. C. Vickerman, Anal. Chem. 2011, 83, 3793, https://doi.org/10.1021/ac200288v.

[8] H. Tian, D. Maciążek, Z. Postawa, B. J. Garrison, N. Winograd, J. Am. Soc. Mass Spectrom. 2016, 27, 1476, https://doi.org/10.1007/s13361-016-1423-z.

[9] S. Sheraz née Rabbani, I. Berrueta Razo, T. Kohn, N. P. Lockyer, J. C. Vickerman, Anal. Chem. 2015, 87, 2367, https://doi.org/10.1021/ac4013732.

[10] F. Kollmer, W. Paul, M. Krehl, E. Niehuis, Surf. Interface Anal. 2013, 45 , 312, https://doi.org/10.1002/sia.5093.

[11] P. Van der Heide, 'Secondary ion mass spectrometry: an introduction to principles and practices', John Wiley \& Sons, 2014.

[12] P. Hoppe, S. Cohen, A. Meibom, Geostand. Geoanal. Res. 2013, 37, 111, https://doi.org/10.1111/j.1751-908X.2013.00239.x.

[13] X.-H. Li, Q.-L. Li, Y. Liu, G.-Q. Tang, J. Anal. At. Spectrom. 2011, 26, 352 , https://doi.org/10.1039/C0JA00073F.

[14] F. Z. Page, T. Ushikubo, N. T. Kita, L. R. Riciputi, J. W. Valley, Am. Mineral. 2007, 92, 1772, https://doi.org/10.2138/am.2007.2697

[15] M. J. Whitehouse, Geostand. Geoanal. Res. 2013, 37, 19 https://doi.org/10.1111/j.1751-908X.2012.00188.x.

[16] Y. Liu, X.-H. Li, G.-Q. Tang, Q.-L. Li, X.-C. Lio, H.-M. Yu, F. Huang, J. Anal. At. Spectrom. 2019, 34, 906, https://doi.org/10.1039.C8JA00431E. 
[17] C. A. Crow, K. D. McKeegan, D. E. Moser, Geochim. Cosmochim. Acta 2017, 202, 264, https://doi.org/10.1016/j.gca.2016.12.019.

[18] K. D. McKeegan, A. P. A. Kallio, V. S. Heber, G. Jarzebinski, P. H. Mao, C. D. Coath, T. Kunihiro, R. C. Wiens, J. E. Nordholt, R. W. Moses, Science 2011, 332, 1528, https://doi.org/10.1126/science.1204636.

[19] M. A. Kusiak, M. J. Whitehouse, S. A. Wilde, A. A. Nemchin, C. Clark, Geology 2013, 41, 291, https://doi.org/10.1130/G33920.1.

[20] J. Aléon, M. Chaussidon, M. Champenois, D. Mangin, Geostandards Newsletter 2001, 25, 417.

[21] M. C. Jollands, E. Bloch, O. Müntener, Geology 2020, 48, 654, https://doi.org/10.1130/G47238.1.

[22] C. W. Magee, R. E. Honig, Surf. Interface Anal. 1982, 4, 35, https://doi.org/10.1002/sia.740040202.

[23] E. Zinner, Scanning 1980, 3, 57.

[24] A. Benninghoven, F. G. Rudenauer, H. W. Werner, 'Secondary ion mass spectrometry: basic concepts, instrumental aspects, application and trends', Wiley-Interscience, 1987.

[25] R. E. Honig, Int. J. Mass Spectrom. Ion Proc. 1985, 66, 31, https://doi.org/10.1016/0168-1176(85)83018-4

[26] N. T. Kita, T. Ushikubo, B. Fu, J. W. Valley, Chem. Geol. 2009, 264, 43, https://doi.org/10.1016/j.chemgeo.2009.02.012.

[27] G. Slodzian, Appl. Surf. Sci. 2004, 231, 3 , https://doi.org/10.1016/j.apsusc.2004.03.015.

[28] G.Slodzian,F.Hillion,F.J.Stadermann,E.Zinner,Appl.Surf.Sci. 2004,231,874, https://doi.org/10.1016/j.apsusc.2004.03.155

[29] J. M. Eiler, C. Graham, J. W. Valley, Chem. Geol. 1997, 138, 221, https://doi.org/10.1016/S0009-2541(97)00015-6.

[30] J. Isa, I. E. Kohl, M.-C. Liu, J. T. Wasson, E. D. Young, K. D. McKeegan, Chem. Geol. 2017, 458, 14, https://doi.org/10.1016/j.chemgeo.2017.03.020.

[31] A. Didier, B. Putlitz, L. P. Baumgartner, A.-S. Bouvier, T. W. Vennemann, Chem. Geol. 2017, 450, 199, https://doi.org/10.1016/j.chemgeo.2016.12.031.

[32] A. Vho, D. Rubatto, B. Putlitz, A.-S. Bouvier, Geostand. Geoanal. Res. 2020, 44, 459, https://doi.org/10.1111/ggr.12324.

[33] J. Villeneuve, M. Chaussidon, Y. Marrocchi, Z. Deng, E. B. Watson, Rapid Commun. Mass Spectrom. 2019, 33, 1589, https://doi.org/10.1002/rcm.8508.

[34] G. Siron, L. Baumgartner, A.-S. Bouvier, B. Putlitz, T. Vennemann, Geostand. Geoanal. Res. 2017, 41, 243, https://doi.org/10.1111/ggr.12148.

[35] M. G. Śliwiński, K. Kitajima, M. J. Spicuzza, I. J. Orland, A. Ishida, J. H. Fournelle, J. W. Valley, Geostand. Geoanal. Res. 2018, 42, 49, https://doi.org/10.1111/ggr.12194.

[36] A. Wudarska, E. Slaby, M. Wiedenbeck, J. D. Barnes, M. Bonifacie, N. C. Sturchio, G. Bardoux, F. Couffignal, J. Glodny, L. Heraty, Geostand. Geoanal. Res. 2021, 45, 121, https://doi.org/10.1111/ggr.12366.

[37] C. Rollion-Bard, M. Chaussidon, C. France-Lanord, Earth Planetary Sci. Lett. 2003, 215, 275, https://doi.org/10.1016/S0012-821X(03)00391-1.

[38] C. Rollion-Bard, J. Marin-Carbonne, J. Anal. At. Spectrom. 2011, 26, 1285 https://doi.org/10.1039/C0JA00213E.

[39] G. L. Fisher, A. L. Bruinen, N. O. Potocnik, J. S. Hammond, S. R. Bryan, P. E. Larson, R. M. A. Heeren, Anal. Chem. 2016, 88, 6433, https://doi.org/10.1021/acs.analchem.6b01022.

[40] S. Bai, P. M. Da, C. Li, Z. P. Wang, Z. C. Yuan, F. Fu, M. Kawecki, X. J. Liu, N. Sakai, J. T. W. Wang, S. Huettner, S. Buecheler, M. Fahlman, F. Gao, H. J. Snaith, Nature 2019, 571, 245, https://doi.org/10.1038/s41586-019-1357-2.

[41] H. L. Bloomfield, H. Y. Nie, Surf. Interface Anal. 2017, 49, 1379, https://doi.org/10.1002/sia.6315.

[42] M. Collin, S. Gin, P. Jollivet, L. Dupuy, V. Dauvois, L. Duffours, Npj Mat. Degrad. 2019, 3, https://doi.org/10.1038/s41529-019-0076-3.

[43] B. Gong, C. E. Marjo, Surf. Interface Anal. 2016, 48, 422, https://doi.org/10.1002/sia.5928.

[44] S. P. Harvey, Z. Li, J. A. Christians, K. Zhu, J. M. Luther, J. J. Berry, ACS Appl. Mater. Inter. 2018, 10, 28541, https://doi.org/10.1021/acsami.8b07937.

[45] S. I. Iida, M. Terashima, K. Mamiya, H. Y. Chang, S. Sasaki, A. Ono, T. Kimoto, T. Miyayama, J. Vac. Sci. Technol. B 2021, 39, https://doi.org/10.1116/6.0001044.

[46] C. Bouvier, H. Glanville, L. de Viguerie, C. Merucci, P. Walter, A. Brunelle, Anal. Chem. 2021, 93, 4463, https://doi.org/10.1021/acs.analchem.0c04471.

[47] K. Keune, J. J. Boon, Stud. Conserv. 2007, 52, 161, https://doi.org/10.1179/sic.2007.52.3.161.

[48] E. Cuypers, B. Flinders, C. M. Boone, I. J. Bosman, K. J. Lusthof, A. C. Van Asten, J. Tytgat, R. M. A. Heeren, Anal. Chem. 2016, 88, 3091, https://doi.org/10.1021/acs.analchem.5b03979.

[49] R. Erne, L. Bernhard, M. Kawecki, M. R. Baumgartner, T. Kraemer, Analyst 2020, 145, 4906, https://doi.org/10.1039/c9an02577d.

[50] T. D. Thandauthapani, A. J. Reeve, A. S. Long, I. J. Turner, J. S. Sharp, Sci. Justice 2018, 58, 405, https://doi.org/10.1016/j.scijus.2018.08.004.

[51] E. Gaillou, J. E. Post, D. Rost, J. E. Butler, Am. Mineral. 2012, 97, 1, https://doi.org/10.2138/am.2012.3925.
[52] A. F. A. Marques, S. D. Scott, R. N. S. Sodhi, Surf. Interface Anal. 2011, 43 , 436, https://doi.org/10.1002/sia.3594.

[53] F. M. McCubbin, A. Steele, H. Nekvasil, A. Schnieders, T. Rose, M Fries, P. K. Carpenter, B. L. Jolliff, Am. Mineral. 2010, 95, 1141, https://doi.org/10.2138/am.2010.3448.

[54] S. D. Montalvo, S. M. Reddy, D. W. Saxey, W. D. A. Rickard, D. Fougerouse, Z. Quadir, T. E. Johnson, Chem. Geol. 2019, 507, 85, https://doi.org/10.1016/j.chemgeo.2018.12.039.

[55] S. Pabst, T. Zack, I. P. Savov, T. Ludwig, D. Rost, E. P. Vicenzi, Am. Mineral. 2011, 96, 1112, https://doi.org/10.2138/am.2011.3709.

[56] S. Rinnen, C. Stroth, A. Risse, C. Ostertag-Henning, H. F. Arlinghaus, Appl. Surf. Sci. 2015, 349, 622, https://doi.org/10.1016/j.apsusc.2015.04.231.

[57] F. Betancourt, A. Kiss, I. Krejci, T. Bortolotto, Materials 2021, 14, https://doi.org/10.3390/ma14164535.

[58] M. Angelo, S. C. Bendall, R. Finck, M. B. Hale, C. Hitzman, A. D. Borowsky, R. M. Levenson, J. B. Lowe, S. D. Liu, S. C. Zhao, Y. Natkunam, G. P. Nolan, Nat. Med. 2014, 20, 436, https://doi.org/10.1038/nm.3488.

[59] L. Keren, M. Bosse, D. Marquez, R. Angoshtari, S Jain, S. Varma, S. R. Yang, A. Kurian, D. Van Valen, R. West, S. C. Bendall, M. Angelo, Cell 2018, 174, 1373, https://doi.org/10.1016/j.cell.2018.08.039.

[60] K. D. Nilsson, N. Neittaanmaki, O. Zaar, T. B. Angerer, J. Paoli, J. S Fletcher, Biointerphases 2020, 15, https://doi.org/10.1116/6.0000340.

[61] M. A. Robinson, D. J. Graham, F. Morrish, D. Hockenbery, L. J. Gamble, Biointerphases 2016, 11, https://doi.org/10.1116/1.4929633.

[62] H. F. Wehrl, J. Schwab, K. Hasenbach, G. Reischl, G. Tabatabai, L. Quintanilla-Martinez, F. Jiru, K. Chughtai, A. Kiss, F. Cay, D. Bukala, R. M. A. Heeren, B. J. Pichler, A. W. Sauter, Cancer Res. 2013, 73, 1470, https://doi.org/10.1158/0008-5472.Can-12-2532.

[63] B. Cillero-Pastor, G. Eijkel, A. Kiss, F. J. Blanco, R. M. A. Heeren, Anal. Chem. 2012, 84, 8909, https://doi.org/10.1021/ac301853q.

[64] L. Carlred, V. Vukojevic, B. Johansson, M. Schalling, F. Hook, P. Sjovall, Biointerphases 2016, 11, https://doi.org/10.1116/1.4940215.

[65] N. Tahallah, A. Brunelle, S. De La Porte, O. Laprevote, J. Lipid Res. 2008 49, 438, https://doi.org/10.1194/jlr.M700421-JLR200.

[66] S. Aoyagi, M. Hayama, U. Hasegawa, K. Sakai, T. Hoshi, M. Kudo, Appl. Surf. Sci. 2004, 231, 411, https://doi.org/10.1016/j.apsusc.2004.03.149.

[67] N. O. Potocnik, G. L. Fisher, A. Prop, R. M. A. Heeren, Anal. Chem. 2017, 89, 8223, https://doi.org/10.1021/acs.analchem.7b02573.

[68] L. MacAleese, M. C. Duursma, L. A. Klerk, G. Fisher, R. M. A. Heeren, $J$ Proteomics 2011, 74, 993, https://doi.org/10.1016/j.jprot.2011.02.009.

[69] M.-N. Decraene, J. Marin-Carbonne, A.-S. Bouvier, J. Villeneuve, N. Bouden, B. Luais, E. Deloule, Rapid Commun. Mass Spectrom. 2021, 35, e8986, https://doi.org/10.1002/rcm.8986.

[70] M.-C. Liu, K. D. McKeegan, T. M. Harrison, G. Jarzebinski, L. Vltava, Int. J. Mass Spectrom. 2018, 424, 1, https://doi.org/10.1016/j.ijms.2017.11.007 .

[71] N. Bouden, J. Villeneuve, Y. Marrocchi, E. Deloule, E. Füri, A. Gurenko, L. Piani, E. Thomassot, P. Peres, F. Fernandes, Front. Earth Sci. 2021, 8 , 724.

[72] S. Seitz, L. P. Baumgartner, A.-S. Bouvier, B. Putlitz, T. Vennemann, Geostand. Geoanal. Res. 2017, 41, 69, https://doi.org/10.1111/ggr.12133.

[73] M. Manzini, A.-S. Bouvier, J. D. Barnes, M. Bonifacie, E. F. Rose-Koga, P. Ulmer, N. Métrich, G. Bardoux, J. Williams, G. D. Layne, Chem. Geol. 2017, 449, 112, https://doi.org/10.1016/j.chemgeo.2016.12.002.

[74] J. Troch, B. S. Ellis, A. K. Schmitt, A.-S. Bouvier, O. Bachmann, Contrib. Mineral. Petrol. 2018, 173, 1, https://doi.org/10.1007/s00410-018-1481-2.

[75] E. De Boever, D. Jaramillo-Vogel, A.-S. Bouvier, N. Frank, A. SchröderRitzrau, L. Baumgarter, R. Swennen, A. Foubert, The Depositional Record 2021, 1, https://doi.org/10.1002/dep2.143.

[76] F. Bégué, L. P. Baumgartner, A.-S. Bouvier, M. Robyr, Earth Planetary Sci. Lett. 2019, 519, 264, https://doi.org/10.1016/j.epsl.2019.05.024.

[77] R. Lafay, L. P. Baumgartner, B. Putlitz, G. Siron, Terra Nova 2019, 31, 94, https://doi.org/10.1111/ter.12373.

[78] K. Marger, M. Harlaux, A. Rielli, L. P. Baumgartner, A. Dini, B L. Dutrow, A.-S. Bouvier, Geostand. Geoanal. Res. 2020, 44, 593, https://doi.org/10.1111/ggr.12326.

[79] G. O. Gonçalves, C. Lana, R. Scholz, I. S. Buick, A. Gerdes, S. L. Kamo, F. Corfu, D. Rubatto, M. Wiedenbeck, H. A. Nalini Jr, Geostand. Geoanal. Res. 2018, 42, 25, https://doi.org/10.1111/ggr.12192.

[80] E. Ricchi, E. Gnos, D. Rubatto, M. J. Whitehouse, T. Pettke, Swiss J. Geosci. 2020, 113, 1, https://doi.org/10.1186/s00015-020-00378-y.

[81] M. Barboni, P. Boehnke, A. K. Schmitt, T. M. Harrison, P. Shane, A.-S Bouvier, L. Baumgartner, Proc. Natl. Acad. Sci. USA 2016, 113, 13959, https://doi.org/10.1073/pnas.1616129113.

[82] M. Tedeschi, P. Lanari, D. Rubatto, A. PedrosaSoares, J. Hermann, I. Dussin, M. A. P. Pinheiro, A.-S. Bouvier, L. Baumgartner, Lithos 2017, 294-295, 283, https://doi.org/10.1016/j.lithos.2017.09.025.

[83] E. M. Bloch, M. C. Jollands, A. Devoir, A.-S. Bouvier, M. Ibañez-Mejia, L. P. Baumgartner, J. Petrol. 2020, 61, egaa055, https://doi.org/10.1093/petrology/egaa055. 
[84] E. M. Bloch, M. C. Jollands, S. S. Gerstl, A.-S. Bouvier, F. Plane, L. P. Baumgartner, Geochim. Cosmochim Acta 2019, 265, 85, https://doi.org/10.1016/j.gca.2019.09.003.

[85] C. Luisier, L. Baumgartner, G. Siron, T. Vennemann, M. Robyr, Geostand. Geoanal. Res. 2019, 43, 635, https://doi.org/10.1111/ggr.12287.

[86] C. E. Fichtner, M. W. Schmidt, C. Liebske, A.-S. Bouvier, L. P. Baumgartner, Earth Planetary Sci. Lett. 2021, 554, 116659, https://doi.org/10.3929/ethz-b-000454782.

[87] J. Hammerli, N. D. Greber, L. Martin, A.-S. Bouvier, A. I. Kemp, M. L. Fiorentini, J. E. Spangenberg, Y. Ueno, U. Schaltegger, Chem. Geol. 2021, 579, 120242, https://doi.org/10.1016/j.chemgeo.2021.120242.

[88] W. F. Hoover, S. C. Penniston-Dorland, L. P. Baumgartner, A.-S. Bouvier, D. Baker, B. Dragovic, A. Gion, Geostand. Geoanal. Res. 2021, 45, 477, https://doi.org/10.1111/ggr.12383.

[89] M. Harlaux, K. Kouzmanov, S. Gialli, K. Marger, A.-S. Bouvier, L. P. Baumgartner, A. Rielli, A. Dini, A. Chauvet, M. Kalinaj, Earth Planetary Sci. Lett. 2021, 563, 116889, https://doi.org/10.1016/j.eps1.2021.116889.

[90] K. Marger, C. Luisier, L. P. Baumgartner, B. Putlitz, B. L. Dutrow, A.-S Bouvier, A. Dini, Am. Mineral.: J. Earth Planetary Mater. 2019, 104, 1503 , https://doi.org/10.2138/am-2019-7012.

[91] A.-S. Bouvier, M. Manzini, E. F. Rose-Koga, A. R. Nichols, L. P. Baumgartner, Earth Planetary Sci. Lett. 2019, 507, 30, https://doi.org/10.1016/j.eps1.2018.11.036.

[92] V. Alice, R. Daniela, L. Pierre, G. Francesco, R. Daniele, H. Jörg, Contrib Mineral. Petrol. 2020, 175, 1, https://doi.org/10.1007/s00410-020-01745-6.

[93] T. Bovay, D. Rubatto, P. Lanari, Contrib. Mineral. Petrol. 2021, 176, 1, https://doi.org/10.1007/s00410-021-01806-4.

[94] M.-N. Decraene, J. Marin-Carbonne, C. Thomazo, N. Olivier, P. Philippot, H. Strauss, E. Deloule, Geochim. Cosmochim. Acta 2021, 312, 299, https://doi.org/10.1016/j.gca.2021.07.020.

[95] Y. Takado, G. Knott, B. M. Humbel, S. Escrig, M. Masoodi, A. Meibom, A. Comment, Nanomedicine: NBM 2015, 11, 239, https://doi.org/10.1016/j.nano.2014.09.007.

[96] Y. Takado, G. Knott, B. M. Humbel, M. Masoodi, S. Escrig, A. Meibom, A. Comment, J. Chem. Neuroanatomy 2015, 69, 7 , https://doi.org/10.1016/j.jchemneu.2015.09.003.

[97] D. Wacey, Aus. J. Earth Sci. 2012, 59, 153 , https://doi.org/10.1080/08120099.2011.592989.

[98] J. Marin-Carbonne, L. Remusat, M. C. Sforna, C. Thomazo, P. Cartigny, P. Philippot, Geobiology 2018, 16, 121, https://doi.org/10.1111/gbi.12275.

[99] N. McLoughlin, L. A. Wilson, M. D. Brasier, Geobiology 2008, 6, 95, https://doi.org/10.1111/j.1472-4669.2007.00141.x.

[100] D. Wacey, M. R. Kilburn, M. Saunders, J. B. Cliff, C. Kong, A. G. Liu, J. J. Matthews, M. D. Brasier, Geology 2015, 43, 27, https://doi.org/10.1130/G36048.1.

[101] S. Behrens, A. Kappler, M. Obst, Environ. Microbiol. 2012, 14, 2851, https://doi.org/10.1111/j.1462-2920.2012.02724.x

[102] A. E. Dekas, V. J. Orphan, Meth. Enzymol. 2011, 486, 281, https://doi.org/10.1016/B978-0-12-381294-0.00012-2.

[103] D. A. Fike, C. L. Gammon, W. Ziebis, V. J. Orphan, ISME J. 2008, 2, 749 https://doi.org/10.1038/ismej.2008.39.

[104] K. Li, J. Liu, C. R. Grovenor, K. L. Moore, Ann. Rev. Anal. Chem. 2020, 13 273, https://doi.org/10.1146/annurev-anchem-092019- 032524

[105] H. Jiang, M. R. Kilburn, J. Decelle, N. Musat, Curr. Opin. Biotechnol. 2016, 41, 130, https://doi.org/10.1016/j.copbio.2016.06.006.

[106] Y. Morono, M. Ito, F. Inagaki, in 'Microbial Life of the Deep Biosphere', De Gruyter, 2014, pp. 101.

[107] N. Musat, F. Musat, P. K. Weber, J. Pett-Ridge, Curr. Opin. Biotechnol. 2016, 41, 114, https://doi.org/10.1016/j.copbio.2016.06.007.

[108] A. Green-Saxena, A. E. Dekas, N. F. Dalleska, V. J. Orphan, ISME J. 2014 8, 150, https://doi.org/10.1038/ismej.2013.147.

[109] C. He, L. G. Fong, S. G. Young, H. Jiang, J. Invest. Med. 2017, 65, 669.

[110] C. Kopp, M. Wisztorski, J. Revel, M. Mehiri, V. Dani, L. Capron, D Carette, I. Fournier, L. Massi, D. Mouajjah, Zoology 2015, 118, 125, https://doi.org/10.1016/j.zool.2014.06.006.

[111] M. R. Kilburn, D. Wacey, in 'Principles and Practice of Analytical Techniques in Geosciences', 2014, pp. 1-34, https://doi.org/10.1039/9781782625025-0001

[112] C. W. Mueller, P. K. Weber, M. R. Kilburn, C. Hoeschen, M. Kleber, J. Pett-Ridge, Adv. Agronomy 2013, 121, 1, https://doi.org/10.1016/B978-0-12-407685-3.00001-3.
[113] J. Nuñez, R. Renslow, J. B. Cliff III, C. R. Anderton, Biointerphases 2018, 13, 03B301, https://doi.org/10.1116/1.4993628.

[114] M. Steinhauser, Microscopy Microanal. 2020, 26, 2506 , https://doi.org/10.1017/S1431927620021820.

[115] L. E. Wedlock, M. R. Kilburn, R. Liu, J. A. Shaw, S. J. Berners-Price, N. P. Farrell, Chem. Commun. 2013, 49, 6944, https://doi.org/10.1039/C3CC42098A.

[116] S. E. Senyo, M. L. Steinhauser, C. L. Pizzimenti, V. K. Yang, L. Cai, M. Wang, T.-D. Wu, J.-L. Guerquin-Kern, C. P. Lechene, R. T. Lee, Nature 2013, 493, 433, https://doi.org/10.1038/nature11682.

[117] J. Wells, M. R. Kilburn, J. A. Shaw, C. A. Bartlett, A. R. Harvey, S. A. Dunlop, M. Fitzgerald, J. Neurosci. Res. 2012, 90, 606 , https://doi.org/10.1002/jnr.22784.

[118] E. M. Bloch, M. C. Jollands, P. Tollan, F. Plane, A.-S. Bouvier, R. Hervig, A. J. Berry, C. Zaubitzer, S. Escrig, O. Müntener, M Ibañez-Mejia, J. Alleon, A. Meibom, L. P. Baumgartner, J. MarinCarbonne, M. Newville, Earth Planetary Sci. Lett. 2022, 578, 117317, https://doi.org/10.1016/j.eps1.2021.117317.

[119] J. Leitner, P. Hoppe, C. Floss, F. Hillion, T. Henkel, Geochim. Cosmochim. Acta 2018, 221, 255, https://doi.org/10.1016/j.gca.2017.05.003.

[120] L. Breuer, N. J. Popczun, A. Wucher, N. Winograd, J. Phys. Chem. C 2017, 121, 19705, https://doi.org/10.1021/acs.jpcc.7b02596.

[121] A. Longobardo, A. N. Macpherson, J. C. Vickerman, N. P. Lockyer, Surf. Interface Anal. 2013, 45, 525, https://doi.org/10.1002/sia.4951.

[122] D. Lorenc, M. Jerigova, M. Stupavska, D. Velic, Sci. Rep.-UK 2017, 7, https://doi.org/10.1038/s41598-017-06562-9.

[123] T. Stephan, R. Trappitsch, A. M. Davis, M. J. Pellin, D. Rost, M R. Savina, R. Yokochi, N. Liu, Int. J. Mass Spectrom. 2016, 407, 1 , https://doi.org/10.1016/j.ijms.2016.06.001.

[124] S. L. Luxembourg, L. A. McDonnell, T. H. Mize, R. M. A. Heeren, J. Proteome Res. 2005, 4, 671, https://doi.org/10.1021/pr049762+.

[125] L. A. Klerk, N. P. Lockyer, A. Kharchenko, L. MacAleese, P. Y. W. Dankers, J. C. Vickerman, R. M. A. Heeren, Anal. Chem. 2010, 82, 801, https://doi.org/10.1021/ac902587g.

[126] A. Kiss, D. F. Smith, J. H. Jungmann, R. M. A. Heeren, Rapid Commun Mass. Spectrom. 2013, 27, 2745, https://doi.org/10.1002/rcm.6719.

[127] T. Kunihiro, K. Nagashima, H. Yurimoto, in 'Lunar and Planetary Science Conference', 2001, p. 1585.

[128] H. Yurimoto, K. Nagashima, T. Kunihiro, Appl. Surf. Sci. 2003, 203, 793 https://doi.org/10.1016/S0169-4332(02)00825-5.

[129] K. Nagashima, G. R. Huss, K. Kosaka, T. Kunihiro, K. Keil, A. N. Krot, G J. Taylor, H. Yurimoto, in 'Lunar and Planetary Science Conference', 2009, p. 2066.

[130] K. Yamamoto, N. Sakamoto, H. Yurimoto, Surf. Interface Anal. 2010, 42, 1603, https://doi.org/10.1002/sia.3599.

[131] D. Aoki, Y. Matsushita, K. Fukushima, in 'Advances in Plant Phenolics: From Chemistry to Human Health', ACS Publications, 2018, pp. 137 https://doi.org/10.1021/bk-2018-1286.

[132] D. Aoki, Y. Hanaya, T. Akita, Y. Matsushita, M. Yoshida, K. Kuroda, S. Yagami, R. Takama, K. Fukushima, Sci. Rep. 2016, 6, 1, https://doi.org/10.1038/srep31525.

[133] K. Kuroda, T. Fujiwara, T. Imai, R. Takama, K. Saito, Y. Matsushita, K. Fukushima, Surf. Interface Anal. 2013, 45, 215, https://doi.org/10.1002/sia.4979.

\section{License and Terms}

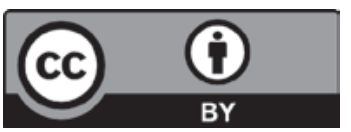

This is an Open Access article under the terms of the Creative Commons Attribution License CC BY 4.0. The material may not be used for commercial purposes.

The license is subject to the CHIMIA terms and conditions: (https://chimia.ch/chimia/about).

The definitive version of this article is the electronic one that can be found at https://doi.org/10.2533/chimia.2022.26 